\title{
Nitrogen dynamics in a highly urbanized coastal area of western Japan: impact of sewage-derived loads
}

\author{
Mitsuyo Saito ${ }^{*}$, Shin-ichi Onodera ${ }^{2}$, Guangzhe Jin ${ }^{2,3}$, Yuta Shimizu $^{4}$ and Masanobu Taniguchi ${ }^{5}$
}

\begin{abstract}
In this study, we examined the nitrogen dynamics of a highly urbanized coastal area, focusing on the impacts of sewage-derived nitrogen. High levels of dissolved inorganic nitrogen were detected in seawater near treated sewage effluent (TSE) discharge points before decreasing in the offshore direction, suggesting that the impact zone of sewage effluent is about 1-2 km from the discharge point. The stable isotope ratios of nitrate and particulate organic nitrogen suggest nitrogen uptake by phytoplankton as well as dilution by offshore seawater, which contributed to a decrease in sewage-derived nitrogen levels. However, the extent of the impact zone was controlled by tidal variations and differences in temperature between the TSE and seawater. Our results also identify nitrogen transport processes, through exchange between seawater and sediment pore water, as an additional important source of nitrogen in the study area.
\end{abstract}

Keywords: Nitrogen dynamics, Coastal area, Urbanization, Sewage, Sediment

\section{Introduction}

Human activities significantly influence the global nitrogen cycle and natural water environments such as rivers and coastal seas (Vitousek et al. 1997; Gruber and Galloway 2008). Marine eutrophication in nearshore environments has been attributed to anthropogenic inputs of nitrogen (Nixon 1995; Howarth and Marino 2006). Water pollution from domestic sewage and industrial waste, in particular, is a critical environmental problem related to the early stages of urbanization, where there is significant growth in population (Onodera 2011). For the Osaka metropolitan area in Japan, pollution of the river and coastal areas was significant until the 1970s. Although this has been improved via the development of sewage treatment systems, the removal of nitrogen requires advanced processing, and relatively large proportions of nitrogen are still discharged in treated sewage effluent to coastal areas due to the absence of this treatment. Powley et al. (2016) estimated that nitrogen inputs from the direct discharge of treated and untreated wastewater from coastal cities to the Mediterranean Sea

\footnotetext{
*Correspondence: misaito@okayama-u.ac.jp

${ }^{1}$ Graduate School of Environmental and Life Science, Okayama University,

3-1-1 Tsushima-naka, Kita-ku, Okayama 700-8530, Japan

Full list of author information is available at the end of the article
}

are of the same order of magnitude as riverine inputs. The effects of excess nitrogen supply from wastewater treatment effluent influence ecosystem structure, as well as nitrogen cycling in receiving waters (Waiser et al. 2011; Drury et al. 2013).

Garside et al. (1976) confirmed the seasonal and spatial distribution of sewage-derived nitrogen and its contribution to much of the nitrogen in the Hudson Estuary, New York, and showed that primary production was not limited by nitrogen availability. Costanzo et al. (2001) applied the nitrogen stable isotope ratios $\left(\delta^{15} \mathrm{~N}\right)$ of marine plants (seagrass, attached macroalgae, and mangroves) to detect and map the impacts of sewagederived nitrogen and confirmed $\delta^{15} \mathrm{~N}$ was elevated near sewage outfalls in Moreton Bay, Australia. Savage (2005) also applied the $\delta^{15} \mathrm{~N}$ of macroalgae (Fucus vesiculosus) and coastal sediments to trace the influence of sewagederived nitrogen. She confirmed this influence was most pronounced within $10 \mathrm{~km}$ of the sewage outfall of the Himmerfjärden embayment of the Baltic Sea.

Eyre (2000) demonstrated the seasonal cycle of nutrient transformation and phytoplankton growth in riverdominated sub-tropical east Australian estuaries. He confirmed that wastewater-derived dissolved inorganic 
nitrogen (DIN) significantly influenced phytoplankton biomass in the estuaries. Pennino et al. (2016) examined the transformations of nitrogen derived from a wastewater treatment facility, based on the nitrogen mass balance and the $\delta^{15} \mathrm{~N}$ and oxygen stable isotope ratios $\left(\delta^{18} \mathrm{O}\right)$ in the tidal Potomac River estuary from Washington, D.C., to the Chesapeake Bay. Estuaries and shallow bays are dynamic environments, influenced by tidal variations and inflow of freshwater from rivers and channels. Therefore, examination of the temporal dynamics of nitrogen in the sewage impact zone is important. However, the detailed transport process and dynamics of sewage-derived nitrogen were not examined in these previous studies. In this study, we examined the nitrogen dynamics of a highly urbanized coastal area of western Japan that is influenced by sewage-derived nitrogen loads.

\section{Methods/Experimental}

\section{Study area}

The study area is located in the northeastern part of Osaka Bay in the Seto Inland Sea in western Japan (Fig. 1). The Seto Inland Sea is the largest semi-enclosed coastal sea in Japan. The area is characterized by a temperate climate, with a mean annual precipitation of $1270 \mathrm{~mm}$ and a mean temperature of $15.1^{\circ} \mathrm{C}$. Osaka Bay is one of the most enclosed bays in the inland sea and has a water surface area of $1447 \mathrm{~km}^{2}$ and mean depth of $30.4 \mathrm{~m}$ (International EMECS Center 2008). The watershed population of the bay is approximately 16 million, including residents of the major cities of Osaka, Kobe, Kyoto, and Sakai (Nishida et al. 2012). Rapid economic growth progressed urbanization significantly in the Osaka metropolitan area from the 1950s to the 1970s. During this period, increased nutrient loads from domestic and industrial activities induced serious eutrophication and an oxygen deficit in the seawater of the bay (ANSIOB 1996; Nakatsuji 1998). Since the 1970s, the regulation of chemical oxygen demand (COD), phosphorus, and nitrogen loads and the development of sewage treatment systems have decreased nutrient loads and the presence of organic matter in the Bay (International EMECS Center 2008; GESAP 2017).

The target area for this study is the inner bay, near the cities of Osaka and Sakai (Fig. 1). Almost 100\% of these

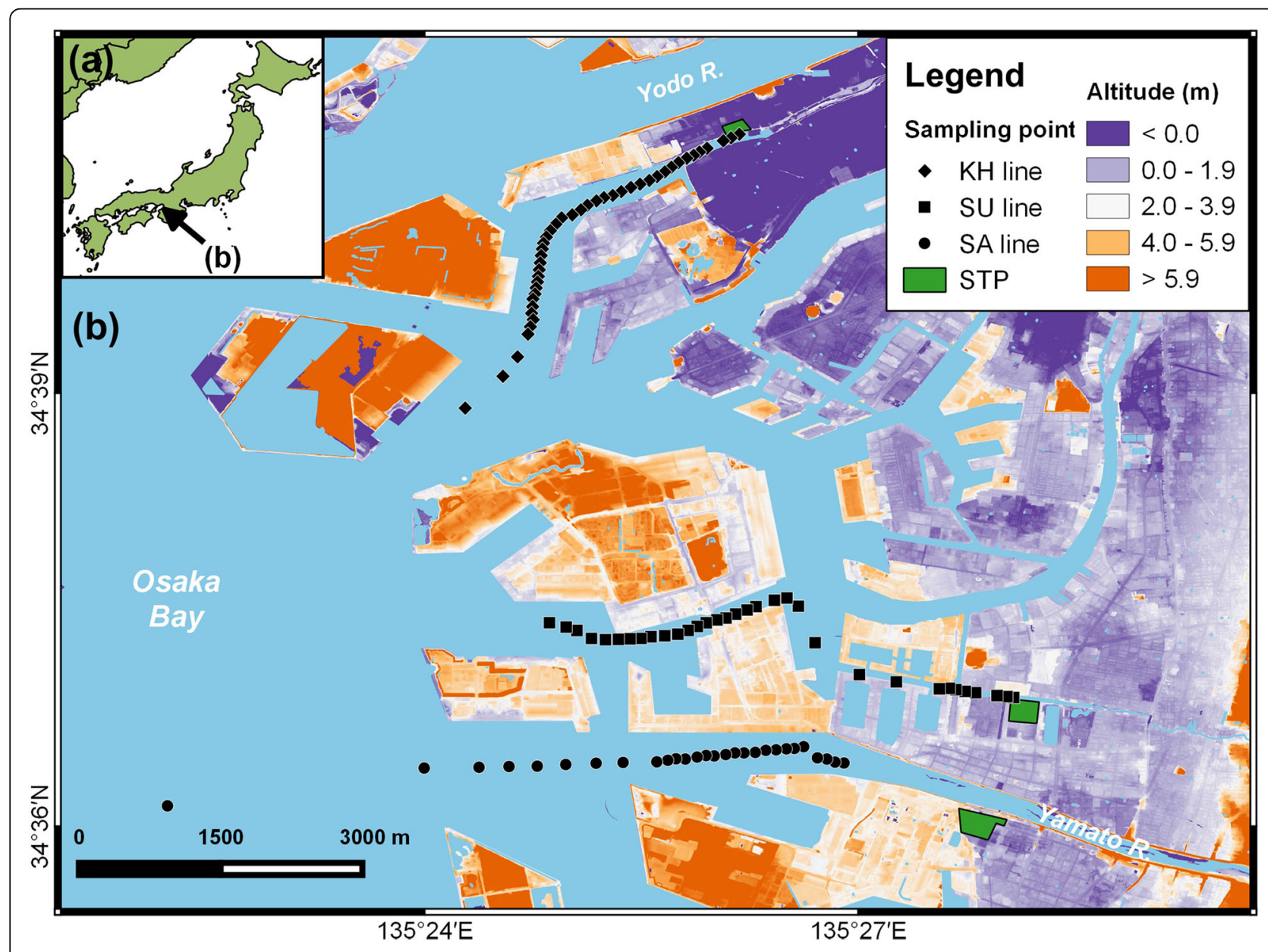

Fig. 1 Map of the study area (a location of the study area, b locations of seawater sampling points on the KH, SU and SA lines and the STPS) 
cities are covered by sewage systems, with 12 public sewage treatment plants (STPs) in Osaka and 3 in Sakai (OPG 2016). However, the removal of nitrogen from this wastewater remains insufficient for preventing nitrogen loading, as most STPs have not yet installed advanced treatment facilities for dissolved nitrogen, such as nitrification-denitrification processes. In Osaka, the average concentration of total nitrogen (TN) and TN load of the influent to these plants are $26 \mathrm{mg} \mathrm{L}^{-1}$ and $44.0 \mathrm{t} \mathrm{day}^{-1}$, respectively, which are reduced to $11 \mathrm{mg} \mathrm{L}^{-1}$ and $18.6 \mathrm{t} \mathrm{day}^{-1}$ in the treated sewage effluent (Osaka City 2016). In Sakai, the average concentration of TN and TN load of the influent to the Sambo STP are $30 \mathrm{mg} \mathrm{L}^{-1}$ and $2.3 \mathrm{t} \mathrm{day}^{-1}$, respectively, which are reduced to $3.4 \mathrm{mg} \mathrm{L}^{-1}$ and $0.3 \mathrm{t} \mathrm{day}^{-1}$ in the treated sewage effluent (SCWSB 2015). In addition, DIN, such as nitrate $\left(\mathrm{NO}_{3}^{-}\right)$and ammonium $\left(\mathrm{NH}_{4}^{+}\right)$, is a major component of the $\mathrm{TN}$ in the treated sewage effluent (TSE) (Osaka City 2017). This indicates that a relatively large proportion of the DIN is discharged in the effluent of these STPs to rivers and coastal areas. Most of the sewage systems in Osaka are "combined systems," which result in increased discharge after high rainfall events because of an inflow of storm water (Broadhead et al. 2013). Therefore, an increase in sewage-derived nitrogen loads from heavy rain has been recognized as a new problem in recent years. We focused on three STPs: Konohana $(\mathrm{KH})$ and Suminoe (SU) in Osaka and Sambo (SA) in Sakai, which are all located in areas of reclaimed land near the coastal bay (STP in Fig. 1). The designed treatment populations for the STPs are 64,302 for $\mathrm{KH}, 386,431$ for $\mathrm{SU}$, and 175,500 for SA (OPG 2017). The treated effluents from KH and SU are discharged directly to the bay, whereas the effluent from SA is discharged to the mouth of the Yamato River.

\section{Field campaigns and sample collection}

Field campaigns were conducted in August and October 2014, February 2015, and September 2016 using a fishing boat. Three observation lines ( $\mathrm{KH}$ line, SU line, and SA line; Fig. 1) were defined from the discharge points of the effluent from the STPs to approximately $5 \mathrm{~km}$ offshore. However, we could not access the discharge point of SA by boat because it is located in the Yamato River channel and the water depth is very shallow $(<2 \mathrm{~m})$. There are no freshwater discharge flows of natural rivers and streams from land to the $\mathrm{KH}$ line except for its TSE; however, there is a small channel between the Yodo River and the line around $2.5 \mathrm{~km}$ from the discharge point (Fig. 1). The $\mathrm{KH}$ and $\mathrm{SU}$ lines are narrow channels, with bottom materials mainly composed of sludge with high organic matter content. The tidal range, tidal condition, air temperature, $24 \mathrm{~h}$ antecedent rainfall, observed lines, and average concentration of dissolved total nitrogen (DTN) in the TSE for the four sampling periods (JMA 2014-2016; Osaka City 2017) are listed in Table 1. The tidal range was larger in February 2015 and September 2016 than in August and October 2014. The air temperature was significantly lower in February 2015 than in the other periods. A $24 \mathrm{~h}$ antecedent rainfall was only observed in September 2016. The $\mathrm{KH}$ line was observed during three different periods to confirm the seasonal and temporal changes of nitrogen dynamics in the study area. The average DTN concentration in the TSE was highest for $\mathrm{KH}\left(14-18 \mathrm{mg} \mathrm{L}^{-1}\right)$ and lowest for SA (approximately $4 \mathrm{mg} \mathrm{L}^{-1}$ ) (SCWSB 2015; Osaka City 2017).

Vertical profiles of water temperature and electrical conductivity (EC) were measured about every $300 \mathrm{~m}$ along the observation lines using a conductivity-temperaturedepth (CTD) sensor (CTD Diver, Schlumberger) and that of chlorophyll-a (Chl-a) concentration via a fluorescent chlorophyll and turbidity sensor (INFINITY-CLW, JFE Advantech Co., Ltd.).

Seawater samples were collected at the surface at approximately $100 \mathrm{~m}$ intervals and from less than $1 \mathrm{~m}$ above the bottom of the coastal seabed at 300 to $1000 \mathrm{~m}$ intervals along the observation lines. At 600 to $1000 \mathrm{~m}$ intervals along the observation lines, sediment samples from the surface of the seabed were collected using an Ekman grab sampler. TSE, river water, sediment pore water, and offshore seawater were collected as endmembers of coastal seawater in the study area. TSE samples were collected from land at the effluent discharge point

Table 1 Tide and weather conditions and average DTN concentration in the TSE during the field campaigns

\begin{tabular}{|c|c|c|c|c|c|c|c|}
\hline Year & Date & Tidal range $(\mathrm{m})$ & Tidal condition & Air temperature $\left({ }^{\circ} \mathrm{C}\right)$ & $\begin{array}{l}24 \mathrm{~h} \text { antecedent } \\
\text { rainfall }(\mathrm{mm})\end{array}$ & Observed lines & $\begin{array}{l}\text { Average DTN concentration } \\
\text { in TSE }\left(\mathrm{mg} \mathrm{L}^{-1}\right)\end{array}$ \\
\hline 2014 & 31 Aug & 0.8 & Ebb-Rising & $27-29$ & 0 & SU Line & 8 \\
\hline \multirow[t]{2}{*}{2014} & $18 \mathrm{Oct}$ & 0.6 & Rising & $15-22$ & 0 & KH Line & 14 \\
\hline & & & & & & SA Line & $4^{a}$ \\
\hline 2015 & 7 Feb & 1.3 & Ebb & $5-10$ & 0 & KH Line & 18 \\
\hline \multirow[t]{2}{*}{2016} & $18 \mathrm{Sep}$ & 1.4 & $\mathrm{Ebb}$ & $25-28$ & 6.5 & KH Line & $14^{\mathrm{b}}$ \\
\hline & & & Rising & & & & \\
\hline
\end{tabular}

${ }^{a}$ Average annual concentration

${ }^{\mathrm{b}}$ Average concentration in September 2014 and 2015 
from SA in August 2013. River water samples were collected $2 \mathrm{~km}$ upstream from the mouth of the Yamato River in August 2013 and September 2014. Sediment pore water was collected using piezometers installed $50 \mathrm{~cm}$ deep using a PVC pipe at the same location for the river water sampling in the Yamato River in August 2013. Offshore seawater samples were collected approximately $7 \mathrm{~km}$ from the STP on the SA line in September and October 2014. Water samples were filtered in the field using $0.2 \mu \mathrm{m}$ cellulose ester filters for analysis of nutrients and stable isotopes and $0.7 \mu \mathrm{m}$ glass microfiber filters for analysis of particulate organic matter (POM). The samples of water and filtrates were stored in a freezer until analysis.

\section{Chemical and isotopic analyses}

DIN as a combination of $\mathrm{NO}_{3}^{-}$, nitrite $\left(\mathrm{NO}_{2}^{-}\right)$, and $\mathrm{NH}_{4}^{+}$; DTN; and dissolved inorganic phosphorus (DIP) measured as phosphate $\left(\mathrm{PO}_{4}^{3-}\right)$ in water samples were determined using a continuous-flow automated analyzer (SWAAT; BL TEC K. K.). Concentrations of dissolved organic nitrogen (DON) were calculated from the difference between DTN and DIN. The organic nitrogen content and $\delta^{15} \mathrm{~N}$ of POM and surface sediment samples were determined using an isotope ratio mass spectrometer (Delta V Advantage and Flash EA 1112; Thermo Fisher Scientific, Inc.). The $\delta^{15} \mathrm{~N}$ in $\mathrm{NO}_{3}^{-}$was determined using the bacterial denitrifier method (Sigman et al. 2001) with an isotope ratio mass spectrometer (Delta V Plus; Thermo Fisher Scientific, Inc.).

\section{Results and discussion}

\section{Impact zone of sewage-derived nitrogen}

Figure 2 shows the spatial variations in 2014 of EC, DIN, DON, the molar ratio between DIN and DON (DIN/DON), and DIP in the surface seawater along the three observation lines (KH, SU, and SA), starting from the discharge point of the treated sewage and ending approximately $5 \mathrm{~km}$ offshore. The $\mathrm{KH}$ and SA lines were observed in October, whereas the SU line was observed in August. The tidal and weather conditions, excluding the air temperature, were similar between these two periods (Table 1). The EC was lowest $\left(<21 \mathrm{mS} \mathrm{cm}^{-1}\right)$ and the concentration of nutrients and DON was highest (DIN > $3.0 \mathrm{mg} \mathrm{L}^{-1}$, DIP > $0.17 \mathrm{mg} \mathrm{L}^{-1}$, and DON > $0.7 \mathrm{mg} \mathrm{L}^{-1}$ ) at the STPs. DIN, mostly $\mathrm{NO}_{3}^{-}$and $\mathrm{NH}_{4}^{+}$, was a few times higher than DON, because DIN is a major form of nitrogen derived from TSE, as reported previously (Osaka City 2017). The DIN concentration for the SU line was higher than that for the $\mathrm{KH}$ line within 1-2 km of the STPs (Fig. 2b). As already mentioned, the DTN concentration in the TSE was lower for SU (8 $\left.\mathrm{mg} \mathrm{L}^{-1}\right)$ than for $\mathrm{KH}\left(14 \mathrm{mg} \mathrm{L}^{-1}\right)$ (Table 1); however, the designed treatment population for $\mathrm{SU}$ is

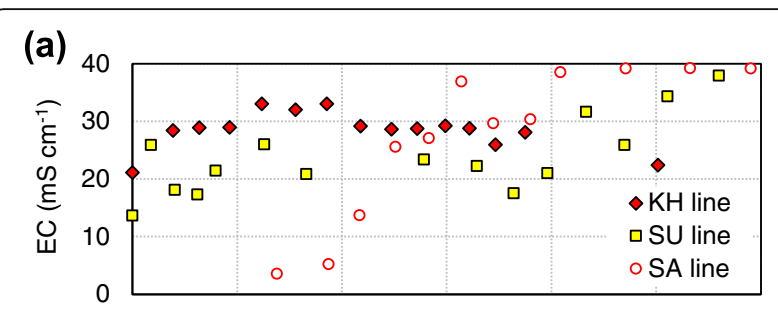

\section{(b)}

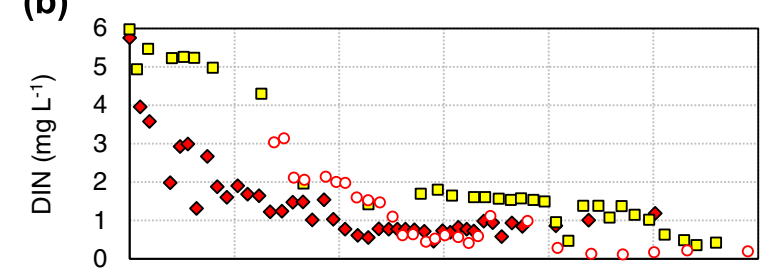

(c)

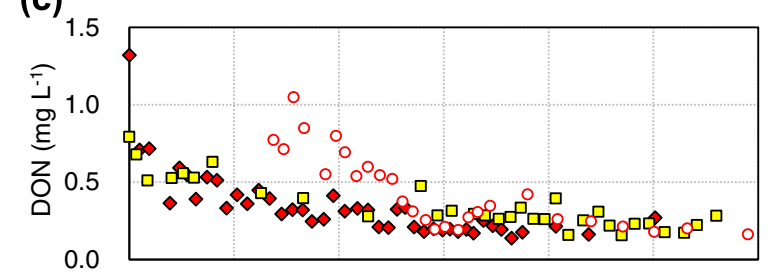

(d)

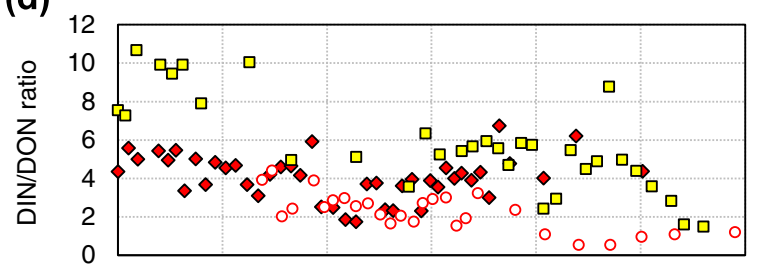

(e)

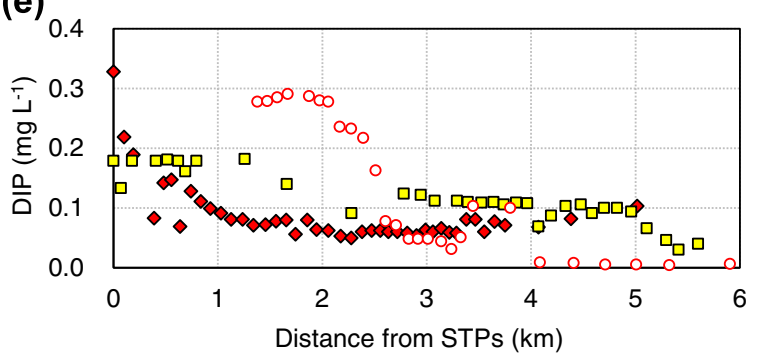

Fig. 2 Spatial variation of $\mathbf{a} E C, \mathbf{b}$ DIN, $\mathbf{c} D O N, \mathbf{d}$ the molar ratio between DIN and DON (DIN/DON), and e DIP in the surface seawater on the SU line in August and the $\mathrm{KH}$ and SA lines in October 2014

six times larger than that for KH (OPG 2017). This indicates that the impact of TSE-derived nitrogen is more significant for the SU line. In addition, the higher temperature conditions in August may have accelerated the decomposition of organic matter and the nitrification process, resulting in elevated DIN concentrations. EC increased and nutrients and DON decreased significantly within $1-2 \mathrm{~km}$ of the STPs through mixing with seawater of the $\mathrm{KH}$ and SU lines. These results indicate that the impact zone of TSEderived nitrogen is about $1-2 \mathrm{~km}$ offshore from the 
STPs. The significantly low EC $\left(<10 \mathrm{mS} \mathrm{cm}^{-1}\right)$ and relatively high DON and DIP in this zone of the SA line may have been influenced by the Yamato River (Fig. 2a-e). The DTN and dissolved total phosphorus (DTP) concentrations in the TSE from SA were approximately 4 and $0.1 \mathrm{mg} \mathrm{L}^{-1}$, respectively (SCWSB 2015). This suggests that the DIP increased $\left(>0.2 \mathrm{mg} \mathrm{L}^{-1}\right)$ as a result of phosphorus desorption via mixing of seawater (Fox et al. 1986). However, the DTN (DIN+DON) concentration in this zone was approximately $4 \mathrm{mg} \mathrm{L}^{-1}$, which was a similar level to that of the TSE. In addition, DIN/DON was similar among the lines. These results suggest that TSE-derived nitrogen as well as the Yamato River may have influenced the SA line.

\section{Seasonal and temporal changes in the sewage impact zone}

The spatial variations of water temperature, EC, Chl-a, $\mathrm{NO}_{3}^{-}-\mathrm{N}$, and $\mathrm{NH}_{4}^{+}-\mathrm{N}$ in the surface seawater of the $\mathrm{KH}$ line between October 2014 and February 2015 are shown in Fig. 3. Water temperature was lower in February than in October because of the difference in air temperature (Table 1). The EC was lower and the $\mathrm{NO}_{3}^{-}-\mathrm{N}$ and $\mathrm{NH}_{4}^{+}-\mathrm{N}$ concentrations were significantly higher in February than in October from the STP to $2 \mathrm{~km}$ offshore. The relatively high Chl-a concentration suggests that phytoplankton were still actively taking up nutrients in February (Fig. 3c). These results suggest that the sewage impact zone expanded in February. As noted previously, the flow of the Yodo River may affect the results for the $\mathrm{KH}$ line through the small channel approximately $2.5 \mathrm{~km}$ from the STP (Fig. 1). This indicates the effects of the TSE caused the expansion of the impact zone.

A slightly higher DTN concentration in the TSE in February $\left(18 \mathrm{mg} \mathrm{L}^{-1}\right)$ than in October $\left(14 \mathrm{mg} \mathrm{L}^{-1}\right)$ may have increased the $\mathrm{NO}_{3}^{-}-\mathrm{N}$ and $\mathrm{NH}_{4}^{+}-\mathrm{N}$ levels near the STP (Table 1). The tidal range was greater in February than in October, and the February observation was conducted during ebb tide (Table 1). This suggests that the plume of TSE-derived nitrogen was transported offshore with less mixing and dilution by seawater. The water temperature was nearly equal to the air temperature in October; however, it was higher than that of air temperature $\left(>10{ }^{\circ} \mathrm{C}\right)$ from the STP to approximately $2 \mathrm{~km}$ offshore in February (Fig. 3a, Table 1). This suggests that another possible cause for the expansion of the impact zone is the difference in water temperature between the TSE and the surface seawater. TSE is usually discharged at more than $20{ }^{\circ} \mathrm{C}$ throughout the year because of the operating parameters of the biological activated sludge treatment process (Hashimoto and Sudo 1986). This would intensify the buoyancy of the effluent plume and allow the plume to extend further offshore during

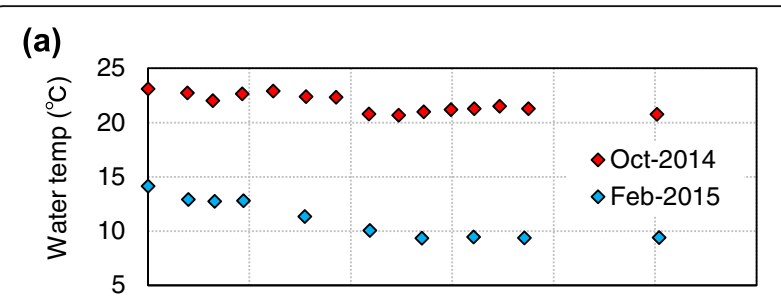

(b)

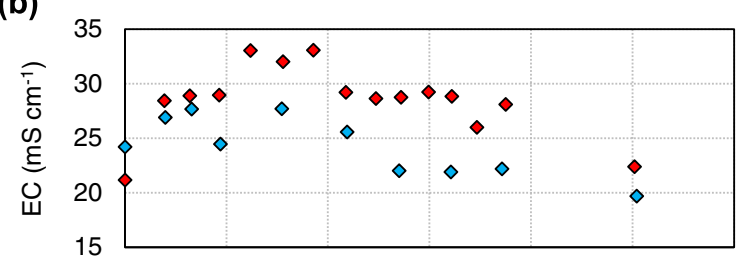

(c)

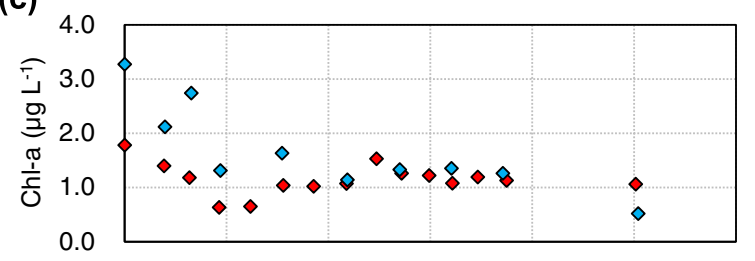

(d)

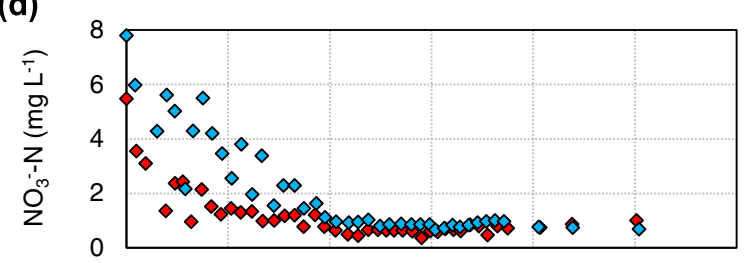

(e)

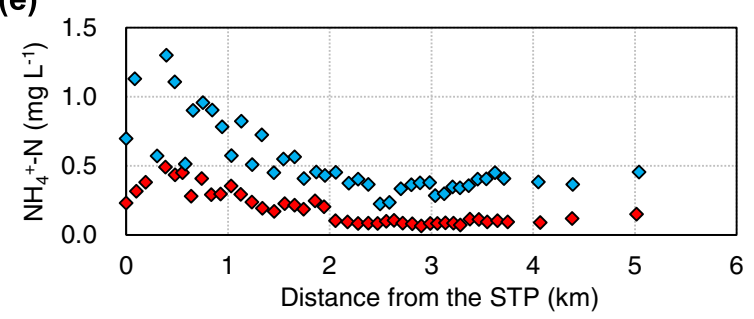

Fig. 3 Spatial variation of a water temperature, $\mathbf{b} \mathrm{EC}, \mathbf{c} \mathrm{Chl}-\mathrm{a}, \mathbf{d} \mathrm{NO}_{3}^{-}-\mathrm{N}$, and $\mathbf{e} \mathrm{NH}_{4}^{+} \mathrm{N}$ in the surface seawater on the $\mathrm{KH}$ line in October 2014 and February 2015

periods of low seawater temperature. The effect of thermal effluent from STPs on water bodies has previously been reported for urban river systems (Nakamuro et al. 2006; Kinouchi et al. 2007).

Next, we discuss the nitrogen dynamics at approximately $2.5 \mathrm{~km}$ from the STP, to examine the effect of TSE-derived nitrogen. As noted above, the influence of the Yodo River inflow should be considered for more than $2.5 \mathrm{~km}$ offshore from the STP on the $\mathrm{KH}$ line. Vertical profiles of EC and Chl-a from the STP to $2.5 \mathrm{~km}$ offshore on the $\mathrm{KH}$ line during the ebb and rising tide periods in September 2016 are shown in Fig. 4. The surface EC at $2.5 \mathrm{~km}$ from the STP was relatively high compared to that of the other sites (Fig. 4a). This 


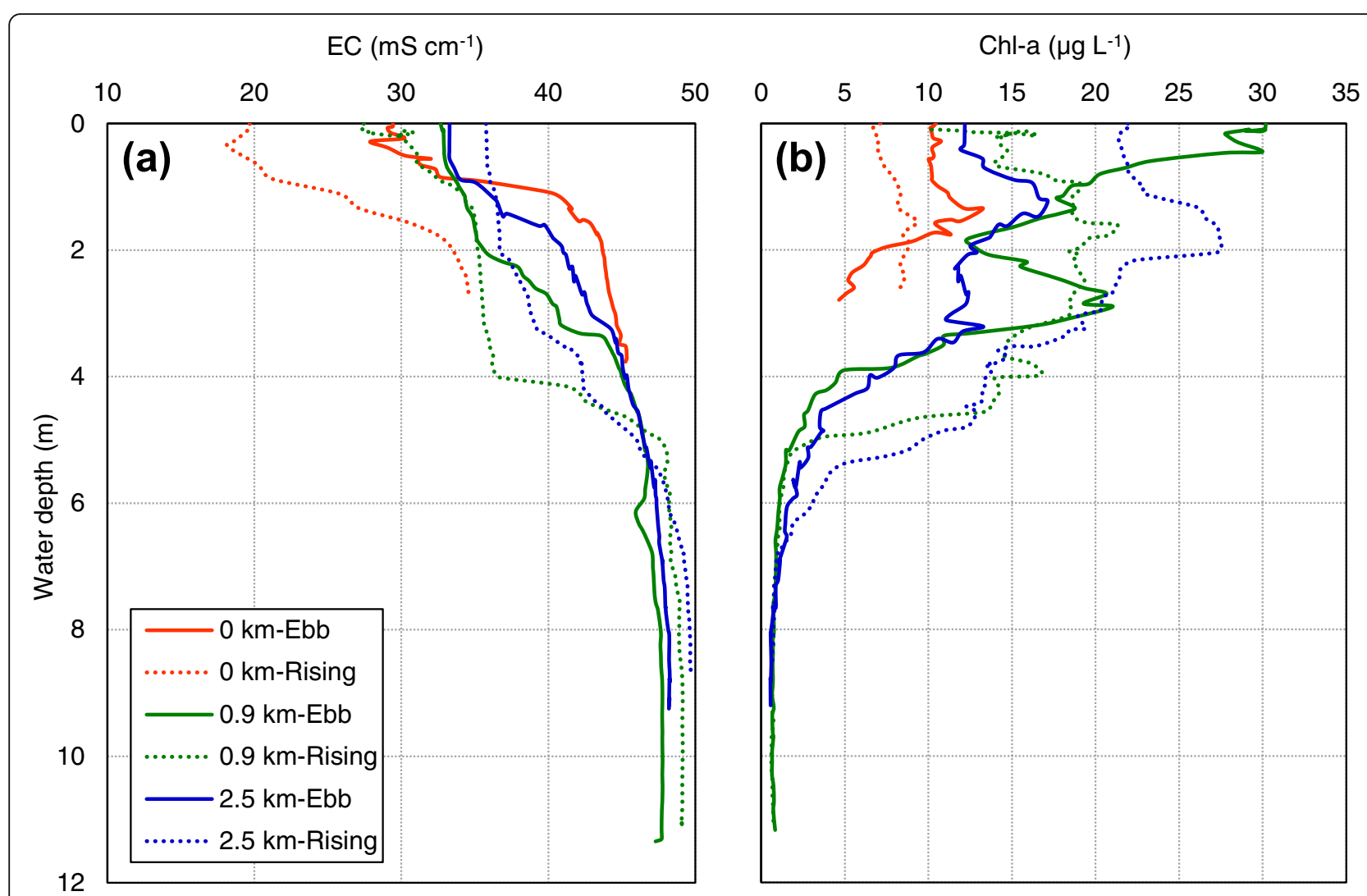

Fig. 4 Vertical profiles of $\mathbf{a}$ EC and $\mathbf{b}$ Chl-a from the STP to $2.5 \mathrm{~km}$ offshore on the $\mathrm{KH}$ line during the ebb and rising tide periods in September 2016

suggests that the influence of the Yodo River inflow was small within $2.5 \mathrm{~km}$ of the STP. The EC at depths of less than $5 \mathrm{~m}$ was relatively high during the ebb tide because the tidal levels in the observation period were higher during the ebb tide than during the rising tide. Both the $\mathrm{EC}$ and the Chl-a concentrations varied significantly between the surface and bottom for both periods. The EC was relatively low and the Chl-a concentration was high at the surface compared to those at the bottom. These results suggest that the surface seawater is significantly affected by TSE-derived nitrogen. The vertical profiles in Fig. 4 suggest that the spatial and temporal variations in DIN should be compared between these two depths.

Figure 5 shows the spatial variations of $\mathrm{EC}, \mathrm{NO}_{3}^{-}-\mathrm{N}$, and $\mathrm{NH}_{4}^{+}-\mathrm{N}$ at the surface and less than $1 \mathrm{~m}$ above the bottom of the seabed for seawater on the $\mathrm{KH}$ line in October 2014 and September 2016. The EC was lower at the surface than at the bottom in both periods (Fig. 5a, b). The $\mathrm{NO}_{3}^{-}-\mathrm{N}$ concentration was relatively higher at the surface than that at the bottom; however, it was significantly lower in September than in October at the surface (Fig. 5c, d). These EC and $\mathrm{NO}_{3}^{-}-\mathrm{N}$ results suggest that the TSE-derived nitrogen was diluted by rainwater in September because of the antecedent rainfall (Table 1). The $\mathrm{NH}_{4}^{+}-\mathrm{N}$ concentration was at a similar level $\left(<0.6 \mathrm{mg} \mathrm{L}^{-1}\right)$ between the two depths in October; however, it was significantly higher at the bottom than at the surface in September (Fig. 5e, f).

The results during the ebb and rising tides were compared in September 2016. The EC was lower during the rising tide than during the ebb tide from the STP to $1.5 \mathrm{~km}$ offshore at the surface (Fig. $5 \mathrm{a}$ ) but only near the STP at the bottom (Fig. 5b). Moreover, the $\mathrm{NO}_{3}^{-}-\mathrm{N}$ and $\mathrm{NH}_{4}^{+}-\mathrm{N}$ concentrations were relatively high during the rising tide in the lower EC zone at the surface (Fig. 5c, e). These results suggest that the TSE-derived nitrogen was transported about $1.5 \mathrm{~km}$ offshore from the STP. In contrast, both the $\mathrm{NO}_{3}^{-}-\mathrm{N}$ and $\mathrm{NH}_{4}^{+}-\mathrm{N}$ concentrations were relatively high during the ebb tide at the bottom. The $\mathrm{NH}_{4}^{+}-\mathrm{N}$ concentration, in particular, was detected at a level more than 10 times higher than the concentration at the surface (Fig. $5 \mathrm{~d}, \mathrm{f}$ ). These results suggest that the sources of nitrogen were different between the surface and the bottom, especially in September.

Previous research confirmed that estuarine circulation flow is dominant in the inner part of Osaka Bay (Nakajima and Fujiwara 2007; Kobayashi et al. 2017). They imply that nitrogen at the bottom layer of the $\mathrm{KH}$ line originated from the bottom seawater of Osaka Bay. However, the reported $\mathrm{NH}_{4}^{+}-\mathrm{N}$ concentrations of the bottom seawater in 

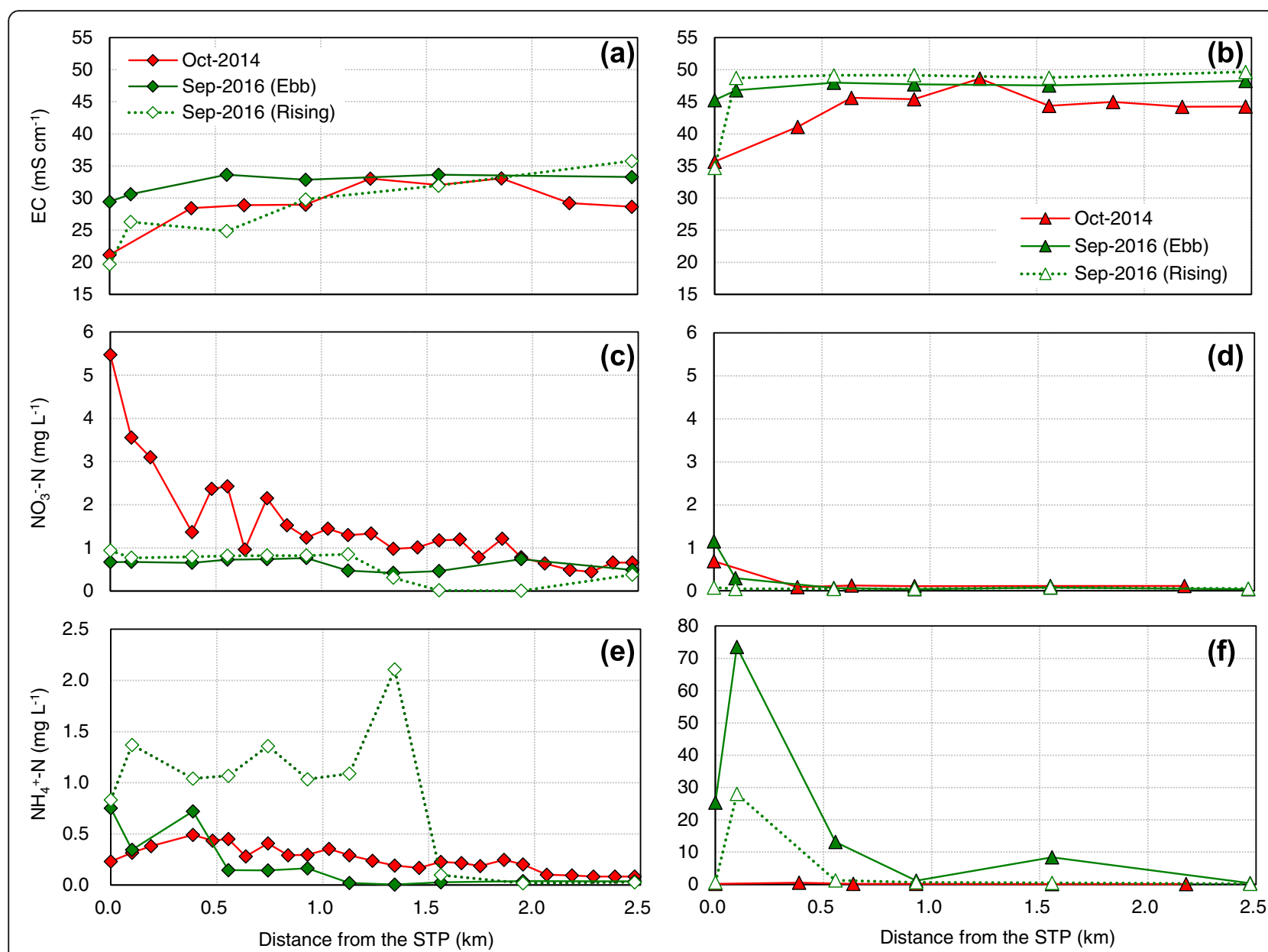

Fig. 5 Spatial variation of $\mathbf{a}, \mathbf{b} \mathrm{EC}, \mathbf{c}, \mathbf{d} \mathrm{NO}_{3}^{-}-\mathrm{N}$, and $\mathbf{e}, \mathbf{f} \mathrm{NH}_{4}^{+}-\mathrm{N}$ in the surface $(\mathbf{a}, \mathbf{c}, \mathbf{e})$ and bottom $(\mathbf{b}, \mathbf{d}, \mathbf{f})$ seawater of the $\mathrm{KH}$ line in October 2014 and September 2016

the bay were less than $0.3 \mathrm{mg} \mathrm{L}^{-1}$ (RIEAFOP 2006-2015), which is much lower than the $\mathrm{NH}_{4}^{+}-\mathrm{N}$ concentrations detected in the bottom layer of the $\mathrm{KH}$ line in September (Fig. 5f). On the other hand, Onodera et al. (2013) confirmed exchange between surface water and sediment pore water caused by tidal variation in the study area. These results suggest that nitrogen supply via exchange between seawater and sediment pore water occurs in the study area.

\section{Nitrogen dynamics in the sewage impact zone}

TSE-derived nitrogen was confirmed to decrease significantly within 1-2 km of the STP (Figs. 2, 3, and 5). Figure 6 shows the relationship between the EC and DIN concentrations and between the Chl-a and particulate organic nitrogen $(\mathrm{PON})$ concentrations in the surface seawater on the $\mathrm{KH}$ line in October 2014 and September 2016. Most of the observed DIN concentrations were lower than the concentration derived via the mixing of TSE and offshore seawater (Fig. 6a). This suggests that the dilution effect via mixing with offshore seawater is a major factor in the reduction of DIN concentrations; however, the effect of nitrogen uptake by phytoplankton should also be considered. Figure $6 \mathrm{~b}$ indicates that the $\mathrm{Chl}-\mathrm{a}$ and PON concentrations correspond relatively closely to each other and that most of the PON originates from phytoplankton. This result also suggests that the biomass of phytoplankton was about 10 times higher in September 2016 than in October 2014. The Chl-a in September 2016 was also significantly higher than in February 2015 (Fig. 3c). As noted above, the bottom materials in the observation lines are mainly composed of sludge with a high content of organic matter. These results suggest that the sediment in these observation lines originated from POM as phytoplankton.

Figure 7 shows a comparison of spatial variation in PON concentrations and in $\delta^{15} \mathrm{~N}$ values for $\mathrm{NO}_{3}^{-}, \mathrm{PON}$, and surface sediment of the $\mathrm{KH}$ line. The PON results for October 2014 and the rising tide period in September 2016 are shown (Fig. 7a, b). The $\delta^{15} \mathrm{~N}$ values for $\mathrm{NO}_{3}^{-}$and sediment for October 2014 are shown (Fig. 7b). As also shown in Fig. 6, the PON concentration was at a high level 

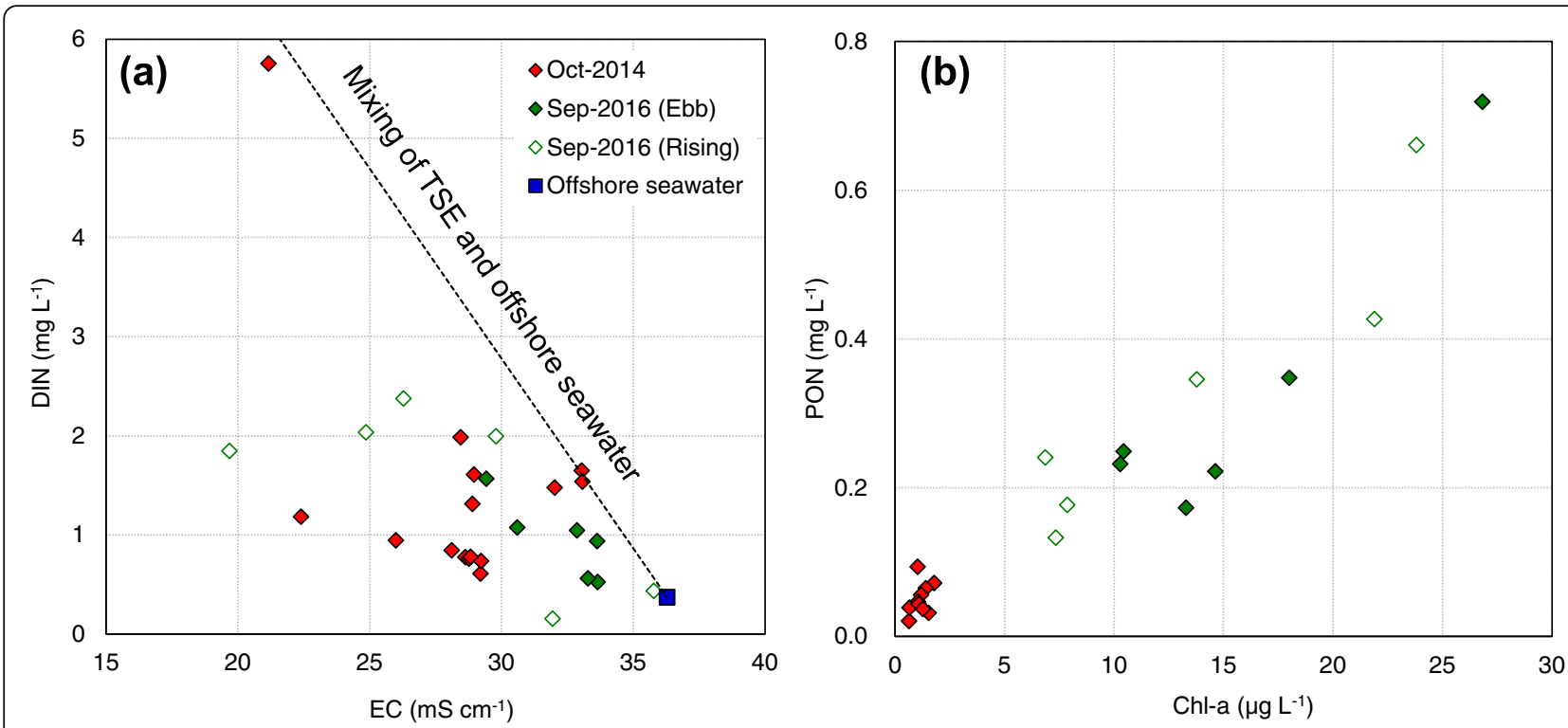

Fig. 6 Relationship between a the EC and DIN concentrations and $\mathbf{b}$ the Chl-a and PON concentrations in the surface seawater of the KH line in October 2014 and September 2016

in September (Fig. 7a). In Fig. 7b, the average values of $\delta^{15} \mathrm{~N}\left(\mathrm{NO}_{3}^{-}\right)$for offshore seawater, river water, pore water, and TSE were also shown as endmembers of the coastal seawater in the study area. The $\delta^{15} \mathrm{~N}\left(\mathrm{NO}_{3}^{-}\right)$value for the $\mathrm{KH}$ line was +8.8 to $+10.8 \%$; however, the offshore seawater, river water, and TSE showed higher values $\left(+12\right.$ to $+14 \%$ ), which suggests the $\delta^{15} \mathrm{~N}\left(\mathrm{NO}_{3}^{-}\right)$for the $\mathrm{KH}$ line may have been influenced by the isotope fractionation via nitrification (Kendall et al. 2007). On the other hand, the lower $\delta^{15} \mathrm{~N}\left(\mathrm{NO}_{3}^{-}\right)$value for pore water $(+5 \%$ ) also suggests a contribution of sedimentderived nitrogen to the $\mathrm{NO}_{3}^{-}$in the $\mathrm{KH}$ line.

Patterns of spatial variation of $\delta^{15} \mathrm{~N}(\mathrm{PON})$ were similar between the two periods (Fig. 7b). It was high at the STP owing to the influence of the TSE, and then decreased before increasing again in the offshore direction, influenced by the mixing with offshore seawater and river water. $\delta^{15} \mathrm{~N}$ was higher in $\mathrm{NO}_{3}^{-}$than in PON, excluding at the STP in October. The result that $\mathrm{NO}_{3}^{-}-\mathrm{N}$ was a major form of DIN at the surface (Fig. 5c) suggests that $\delta^{15} \mathrm{~N}(\mathrm{PON})$ reflected $\delta^{15} \mathrm{~N}\left(\mathrm{NO}_{3}^{-}\right)$and that $\delta^{15} \mathrm{~N}\left(\mathrm{NO}_{3}^{-}\right)$ was enriched by the nitrogen uptake of phytoplankton in October (Waser et al. 1998; Sigman et al. 1999). Waser et al. (1998) estimated through a batch culture method in a laboratory that $\delta^{15} \mathrm{~N}$ fractionation is about $5.2 \%$ during uptake by a coastal diatom (Thalassiosira pseudonana). Thalassiosira spp. are major diatom species observed in the study area (Oshima et al. 2009). Sigman et al. (1999) estimated that $\delta^{15} \mathrm{~N}$ fractionation by phytoplankton uptake is 4-6\%o, based on field observations in the Southern Ocean. For the results of the current study, the average $\delta^{15} \mathrm{~N}\left(\mathrm{NO}_{3}^{-}\right)$value was $9.6 \%$ and $\delta^{15} \mathrm{~N}(\mathrm{PON})$ was $6.9 \%$ in October. The enrichment ratio was smaller than the isotope fractionation reported previously.

The $\delta^{15} \mathrm{~N}(\mathrm{PON})$ in September was lower within $1 \mathrm{~km}$ of the STP and higher than in October in the offshore direction (Fig. 7b). The fact that significantly higher $\mathrm{NH}_{4}^{+}-\mathrm{N}$ concentrations were detected in September than in October (Fig. 5e, f) suggests two possibilities: $\delta^{15} \mathrm{~N}(\mathrm{PON})$ may have been influenced more by $\mathrm{NH}_{4}^{+}$ than by $\mathrm{NO}_{3}^{-}$and the $\delta^{15} \mathrm{~N}(\mathrm{PON})$ fractionation by phytoplankton uptake of lower $\delta^{15} \mathrm{~N}\left(\mathrm{NO}_{3}^{-}\right)$was derived through nitrification. On the other hand, the tidal range was more than two times greater in September than in October (Table 1). This suggests that a greater tidal range would have increased the exchange between seawater and pore water through the coastal sediment (intrusion and discharge) and increased the contribution of pore water with a low $\delta^{15} \mathrm{~N}\left(\mathrm{NO}_{3}^{-}\right)$in September. $\delta^{15} \mathrm{~N}$ was lower than PON for the surface sediment samples in the same period and had a similar value with the $\delta^{15} \mathrm{~N}\left(\mathrm{NO}_{3}^{-}\right)$for pore water (Fig. 7b). The discharge volume of TSE would have been larger in September because of the antecedent rainfall (Table 1). This condition may have intensified the estuarine circulation flow, and exchange between seawater and pore water may have increased in September. It also would have been supported by the high concentration of $\mathrm{NH}_{4}^{+}-\mathrm{N}$ observed in both the bottom and surface seawater samples in September (Fig. 5e, f). The increase in nitrogen supply through sediment during this period would have caused an increase in phytoplankton and PON. However, we require data on 


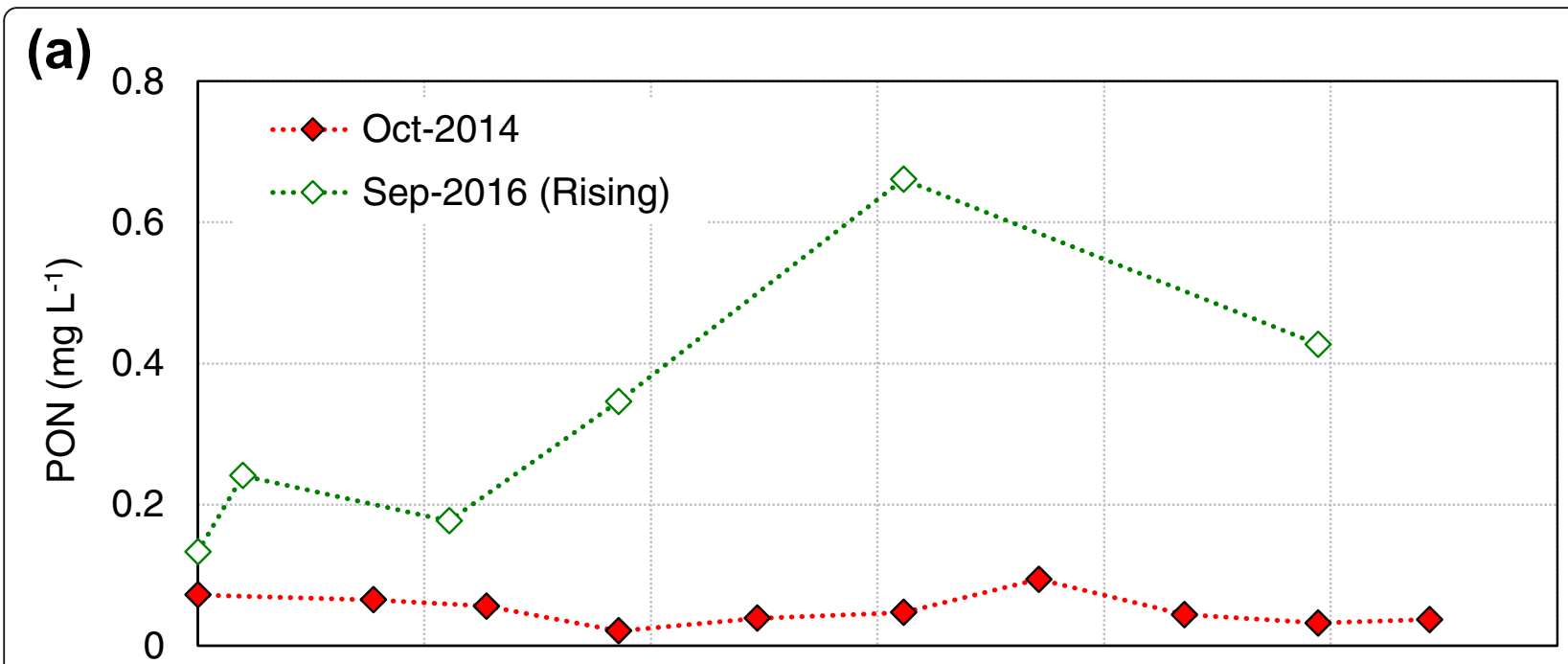

(b)

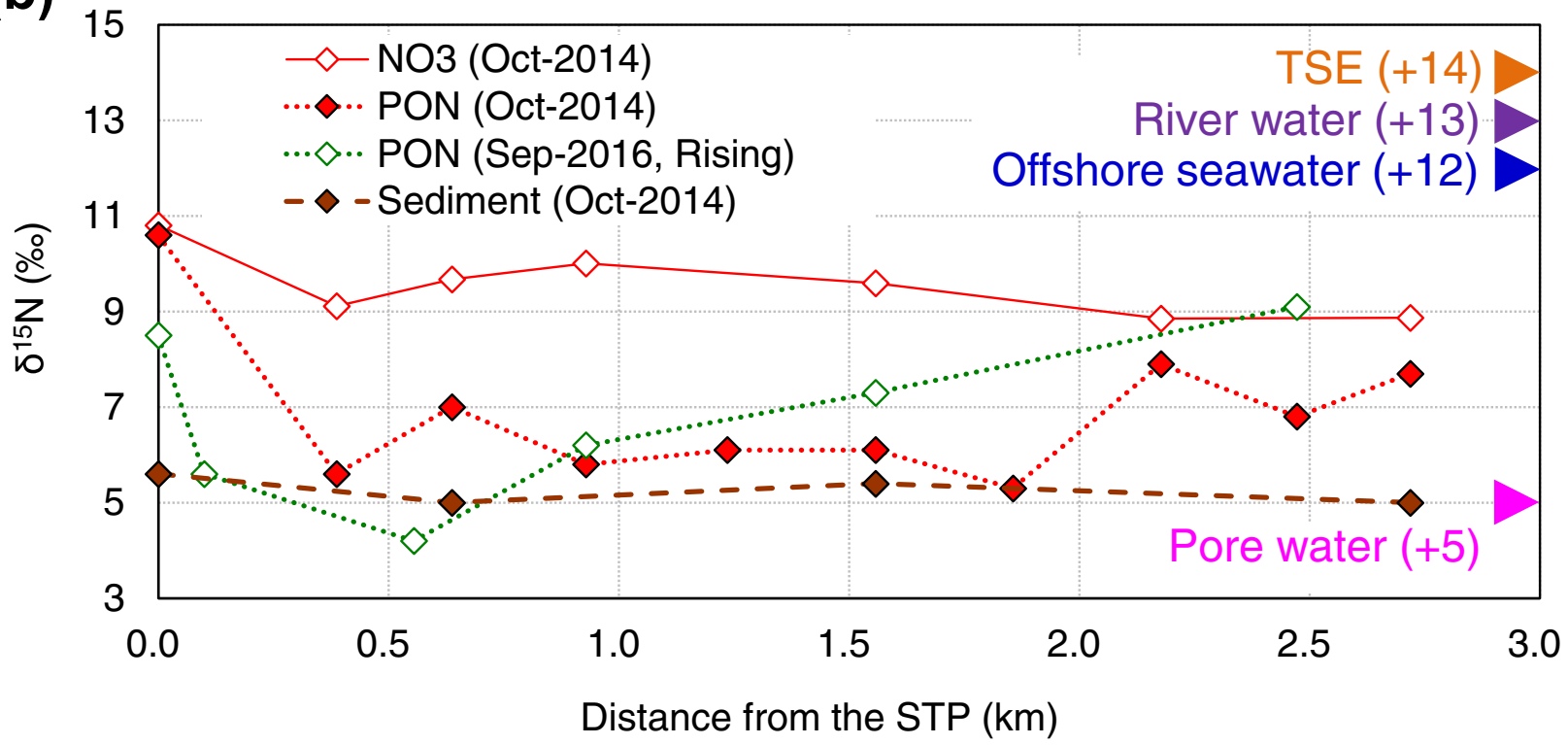

Fig. 7 Spatial variation in a PON concentrations and $\mathbf{b} \delta^{15} \mathrm{~N}$ values for $\mathrm{NO}_{3}^{-}, \mathrm{PON}$, and surface sediment on the $\mathrm{KH}$ line. The values for PON were measured in October 2014 and during the rising tide period in September 2016. The $\delta^{15} \mathrm{~N}$ values for $\mathrm{NO}_{3}^{-}$and sediment were measured in

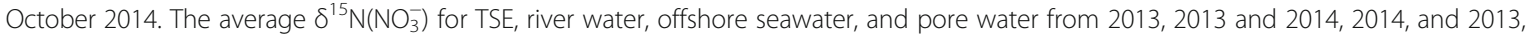
respectively, served as reference values

$\delta^{15} \mathrm{~N}\left(\mathrm{NH}_{4}^{-}\right)$to understand these processes in greater detail. Also, seasonal variation in nitrogen concentration and $\delta^{15} \mathrm{~N}\left(\mathrm{NO}_{3}^{-}\right)$for the endmembers, such as the Yodo River water, will need to be confirmed because previous research pointed out that $\delta^{15} \mathrm{~N}\left(\mathrm{NO}_{3}^{-}\right)$for river water may change according to river discharge (Takagi et al. 2016).

Based on these results, a schematic diagram of nitrogen dynamics in the coastal area, as influenced by sewage-derived loads, is shown in Fig. 8. The sewagederived nitrogen impact zone (SNIZ) via direct discharge of TSE was estimated to be $1-2 \mathrm{~km}$ from the
STPs on the KH and SU lines. This result also suggests that the spatial variation in SNIZ is controlled by tidal variation and the water temperature difference between the TSE and seawater. On the other hand, the SA line was confirmed to be significantly influenced by the Yamato River as well as the TSE. However, similar values of $\delta^{15} \mathrm{~N}\left(\mathrm{NO}_{3}^{-}\right)$for the TSE and Yamato River water suggest the Yamato River is influenced by the STPs located upstream. Conclusively, this study indicates that coastal sediment is another potential source of nitrogen and is transported via exchange between seawater and pore water. More specifically, 


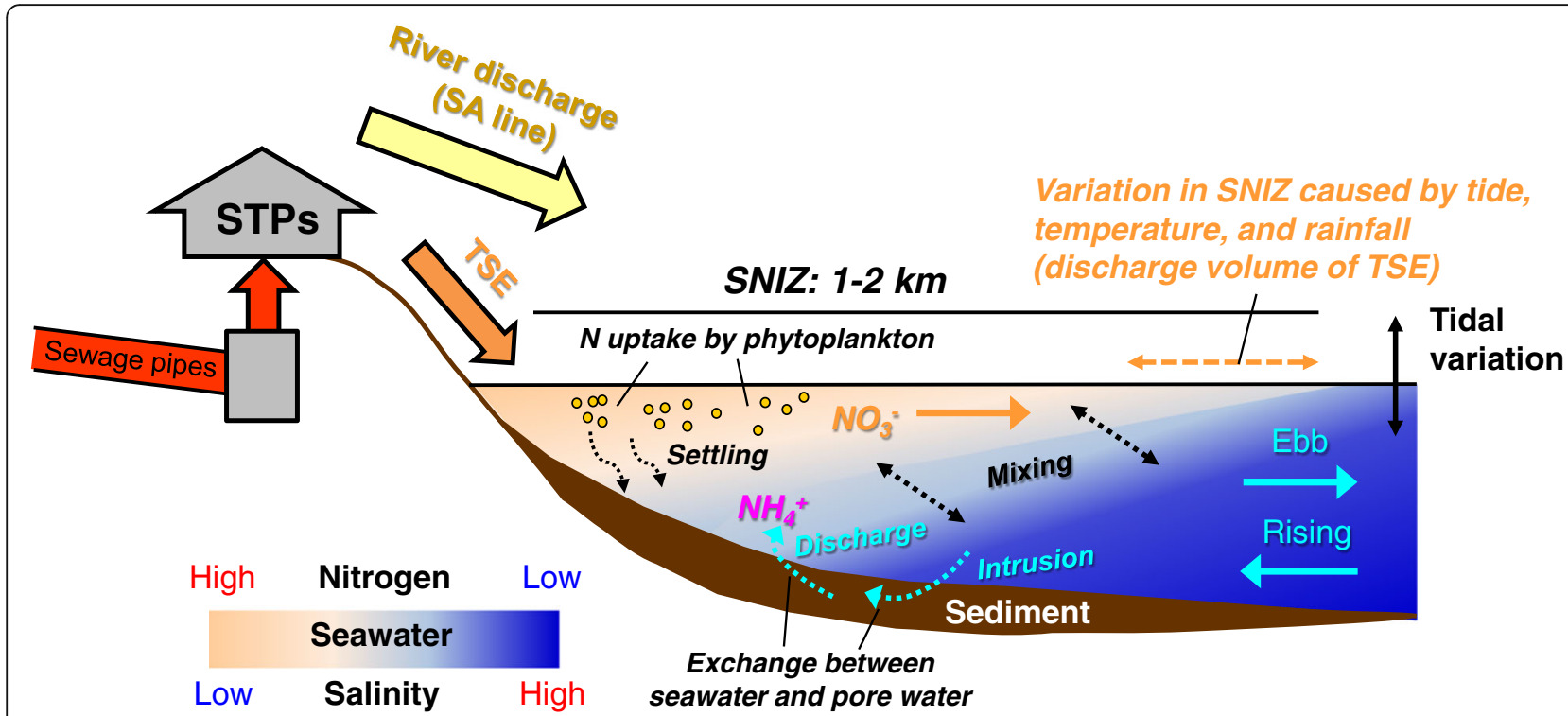

Fig. 8 Schematic diagram of nitrogen dynamics in the coastal sewage-derived nitrogen impact zone (SNIZ). Solid and broken arrows show water movement and suggested processes from the present research, respectively

the sediment may have originated from POM as phytoplankton, which is a secondary product of TSEderived nitrogen. This suggests that the TSE-derived nitrogen in the coastal environment is not only from direct discharge but also from resupply through the sediment.

However, as the study area is influenced by tidal variation and mixing of several endmembers, the nitrogen dynamics should be quite complex compared with closed systems and the open ocean. Our results indicate that temporal changes in mixing ratios of endmembers and nitrogen uptake by phytoplankton influence both the nitrogen concentration and $\delta^{15} \mathrm{~N}$ in this study area, although further research is needed for quantitative evaluation of nitrogen transport processes.

\section{Conclusions}

In this study, nitrogen dynamics were examined for a sewage-influenced coastal area in western Japan. The impact zone of sewage-derived nitrogen by direct discharge of TSE was estimated to be $1-2 \mathrm{~km}$ from STPs in the study area. DIN uptake by phytoplankton as well as dilution by offshore seawater contributed to the decrease in sewage-derived nitrogen. However, the extent of the impact zone was shown to be controlled by tidal variation temporally and water temperature differences between TSE and seawater seasonally. These results also indicate that nitrogen supply via exchange between seawater and sediment pore water is another important source of nitrogen beyond the direct discharge of TSE.

\section{Abbreviations}

SNIZ: Sewage-derived nitrogen impact zone; STPs: Sewage treatment plants; TSE: Treated sewage effluent

\section{Acknowledgements}

We thank Mr. Yutaka Maruyama and Mr. Yusuke Tomozawa for their assistance in our field campaigns and analysis of the samples. MS gratefully acknowledges Dr. Seiko Yoshikawa and Dr. Masahiro Kobayashi, who were session conveners of A-HW16 in Japan Geoscience Union Meeting 2016, for their recommendation of the present study to PEPS. Finally, the authors would like to thank the two reviewers for their helpful comments and suggestions

\section{Funding}

This work was supported by Grant for Environmental Rehabilitation and Creation of the Osaka Bay Area (Head; SO, 2014-2016, Grant Number 280007) and JSPS bilateral joint research projects (Head; SO, 2016-2018). MS was partly funded by the tenure track program of JST for Okayama University (2013-2014).

\section{Authors' contributions \\ MS proposed the topic and conceived and designed the study. SO collaborated with the corresponding author in the construction of the manuscript. GJ, YS, and MT analyzed the data and helped in their interpretation. All authors read and approved the final manuscript.}

\section{Authors' information}

Not applicable

\section{Competing interests}

The authors declare that they have no competing interest.

\section{Publisher's Note}

Springer Nature remains neutral with regard to jurisdictional claims in published maps and institutional affiliations.

\section{Author details}

'Graduate School of Environmental and Life Science, Okayama University, 3-1-1 Tsushima-naka, Kita-ku, Okayama 700-8530, Japan. ${ }^{2}$ Graduate School of Integrated Arts and Sciences, Hiroshima University, 1-7-1 Kagamiyama, Higashi-Hiroshima 739-8521, Japan. ${ }^{3}$ Guangdong Ocean University, 
Huguangyan, Zhanjiang, Guandong Province 524-088, China. ${ }^{4}$ Western Region Agricultural Research Center, National Agriculture and Food Research Organization, 6-12-1 Nishi-Fukatsu-cho, Fukuyama 721-8514, Japan. ${ }^{5}$ Faculty of Systems Engineering, Wakayama University, Sakaedani 930, Wakayama 640-8510, Japan.

Received: 28 June 2017 Accepted: 7 March 2018

Published online: 20 March 2018

\section{References}

ANSIOB (Association for New Social Infrastructure of Osaka Bay) (1996) Communication tool for sustainable development. Institute of Coastal Environment Inc. (in Japanese)

Broadhead AT, Horn R, Lerner DN (2013) Captured streams and springs in combined sewers: a review of the evidence, consequences and opportunities. Water Res 47:4752-4766

Costanzo SD, O'donohue MJ, Dennison WC, Loneragan NR, Thomas M (2001) A new approach for detecting and mapping sewage impacts. Mar Pollut Bull 42:149-156

Drury B, Rosi-Marshall E, Kelly JJ (2013) Wastewater treatment effluent reduces the abundance and diversity of benthic bacterial communities in urban and suburban rivers. Appl Environ Microbiol 79:1897-1905

Eyre BD (2000) Regional evaluation of nutrient transformation and phytoplankton growth in nine river-dominated sub-tropical east Australian estuaries. Mar Ecol Prog Ser 205:61-83

Fox LE, Sager SL, Wofsy SC (1986) The chemical control of soluble phosphorus in the Amazon estuary. Geochim Cosmochim AC 50:783-794

Garside C, Malone TC, Roels OA, Sharfstein BA (1976) An evaluation of sewagederived nutrients and their influence on the Hudson Estuary and New York Bight. Estuar Coast Mar Sci 4:281-289

GESAP (GEC Sanitation Programme) (2017) Sewage works in Osaka, Japan. http:// nett21.gec.jp/GESAP/themes/index.html. Accessed 27 May 2017

Gruber N, Galloway JN (2008) An Earth-system perspective of the global nitrogen cycle. Nature 451:293-296

Hashimoto S, Sudo R (1986) New method of activated sludge. The Industrial Water Institute, Tokyo (in Japanese)

Howarth RW, Marino R (2006) Nitrogen as the limiting nutrient for eutrophication in coastal marine ecosystems: evolving views over three decades. Limnol Oceanogr 51:364-376

International EMECS (Environmental Management of Enclosed Coastal Seas) Center (2008) Environmental conservation of the Seto Inland Sea. https:/www.emecs. or.jp/upload/publish/seto_inland_sea_en.pdf. Accessed 27 May 2017

JMA (Japan Meteorological Agency) (2014-2016) Past metrological data and tidal observation data. http://www.jma.go.jp/jma/menu/menureport.html. Accessed 14 June 2017

Kendall C, Elliott MM, Wankel SD (2007) Tracing anthropogenic inputs of nitrogen to ecosystems. In: Michener R, Lajtha K (eds) Stable isotopes in ecology and environmental science. Blackwell Publishing, Oxford

Kinouchi T, Yagi H, Miyamoto M (2007) Increase in stream temperature related to anthropogenic heat input from urban wastewater. J Hydrol 335:78-88

Kobayashi S, Matsumura Y, Kawamura K, Nakajima M, Yamamoto K, Akiyama S, Ueta $Y$ (2017) Estimation of the origin of dissolved organic matter and biogeochemical cycles of nutrients in Osaka Bay, Japan. J Jpn Soc Water Environ 40:97-105 (in Japanese)

Nakajima M, Fujiwara T (2007) Estuarine circulation and hypoxic water mass in Osaka Bay. Bull Coast Oceanogr 44:157-163 (in Japanese)

Nakamuro K, Okuno T, Takata S, Taguchi H, Inoue T, Ueda A, Fukunaga I, Kagajyo $\mathrm{N}$, Hattori Y, Koi H (2006) Influence of sewage effluent on temperature of urban river water. J Jpn Soc Water Environ 29:177-181 (in Japanese)

Nakatsuji K (1998) Water environment in coastal area. In: Takahashi Y, Kawada K (eds) Water cycle and catchment environment. Iwanami Shoten, Tokyo (in Japanese)

Nishida S, Kawasumi R, Nakatani Y, Murakami Y (2012) Changes and current state of nutrient loads in the Osaka Bay basin. J Jpn Soc Civ Eng Ser G (Environmental Research) 68:III751-III760 (in Japanese)

Nixon SW (1995) Coastal marine eutrophication: a definition, social causes, and future concerns. Ophelia 41:199-219

Onodera S (2011) Subsurface pollution in Asian megacities. In: Taniguchi M (ed) Groundwater and subsurface environments: human impacts in Asian coastal cities. Springer, Tokyo
Onodera S, Saito M, Yoshikawa M, Onishi K, Shimizu Y, Ito H (2013) Nutrient transport and surface water-groundwater interactions in the tidal zone of the Yamato River, Japan. IAHS Publ 361:204-211

OPG (Osaka Prefectural Government) (2016) Municipal coverage of sewage treatment system in 2016 (in Japanese). http://www.pref.osaka.lg.jp/gesui_ jigyo/tokei/fukyuh20.html. Accessed 27 May 2017

OPG (Osaka Prefectural Government) (2017) Statistics of sewage treatment system in Osaka prefecture (in Japanese). http://www.pref.osaka.lg.jp/gesui_ jigyo/tokei/index.html. Accessed 23 Oct 2017

Osaka City (2016) Osaka city environmental white paper (in Japanese). http:// www.city.osaka.lg.jp/kankyo/page/0000370176.html. Accessed 27 May 2017

Osaka City (2017) Results of water quality test of sewage treatment plants (in Japanese). http://www.city.osaka.lg.jp/kensetsu/page/0000009603.html. Accessed 23 June 2017

Oshima A, Nishio T, Fujiwara Y, Shinya M, Kitano M (2009) Dynamics of a red tide of Skeletonema costatum and Thalassiosira spp. (Bacillariophyceae) around the Yume-Shima landfill site in Osaka Bay. Annu Rep Osaka City Inst Public Health Environ Sci 71:49-55

Pennino MJ, Kaushal SS, Murthy SN, Blomquist JD, Cornwell JC, Harris LA (2016) Sources and transformations of anthropogenic nitrogen along an urban river-estuarine continuum. Biogeosciences 13:6211-6228

Powley HR, Dürr HH, Lima AT, Krom MD, Van Cappellen P (2016) Direct discharges of domestic wastewater are a major source of phosphorus and nitrogen to the Mediterranean Sea. Environ Sci Technol 50:8722-8730

RIEAFOP (Research Institute of Environment, Agriculture and Fisheries, Osaka Prefecture) (2006-2015) Annual project reports (in Japanese). http://www. kannousuiken-osaka.or.jp/publication/suisan_shiryo/. Accessed 27 Oct 2017

Savage C (2005) Tracing the influence of sewage nitrogen in a coastal ecosystem using stable nitrogen isotopes. Ambio 34:145-150

SCWSB (Sakai City Waterworks and Sewerage Bureau) (2015) Annual report of sewerage quality in 2015 (in Japanese). http://water.city.sakai.lg.jp/customer/ suisitujhoho/gesuidou/1444721746786.html. Accessed 23 Oct 2017

Sigman DM, Altabet MA, McCorkle DC, Francois R, Fischer G (1999) The $\delta^{15} \mathrm{~N}$ of nitrate in the Southern Ocean: consumption of nitrate in surface waters. Glob Biogeochem CY 13:1149-1166

Sigman DM, Casciotti KL, Andreani M, Barford C, Galanter M, Böhlke JK (2001) A bacterial method for the nitrogen isotopic analysis of nitrate in seawater and freshwater. Anal Chem 73:4145-4153

Takagi S, Kondo M, Kobayashi S, Abo K (2016) Influence on the changes of nutrient conditions and nitrogen stable isotope to the evaluation in nutrient load from land to the sea. J Jpn Soc Civ Eng, Ser B2 (Coastal Engineering) 72: I_1255-I_1260 (in Japanese)

Vitousek PM, Aber JD, Howarth RW, Likens GE, Matson PA, Schindler DW, Schlesinger WH, Tilman DG (1997) Human alteration of the global nitrogen cycle: sources and consequences. Ecol Appl 7:737-750

Waiser MJ, Tumber V, Holm J (2011) Effluent-dominated streams. Part 1: presence and effects of excess nitrogen and phosphorus in Wascana Creek, Saskatchewan, Canada. Environ Toxicol Chem 30:496-507

Waser NAD, Harrison PJ, Nielsen B, Calvert SE (1998) Nitrogen isotope fractionation during the uptake and assimilation of nitrate, nitrite, ammonium, and urea by a marine diatom. Limnol Oceanogr 43:215-224

\section{Submit your manuscript to a SpringerOpen ${ }^{\circ}$ journal and benefit from:}

- Convenient online submission

- Rigorous peer review

- Open access: articles freely available online

- High visibility within the field

- Retaining the copyright to your article

Submit your next manuscript at $\gg$ springeropen.com 